\title{
Extrinsic allergic alveolitis caused by a cold water humidifier
}

\author{
A S ROBERTSON, P S BURGE, G A WIELAND, M H B CARMALT \\ From the Department of Thoracic Medicine, East Birmingham Hospital, and Group for Occupational Lung \\ Diseases, and Selly Oak Hospital, Birmingham
}

\begin{abstract}
Three workers developed classical extrinsic allergic alveolitis while working in a printing works that had a contaminated cold water humidifier. All had nodular shadows on their chest radiographs, reduced gas transfer measurements, and lung biopsy specimens that showed an alveolitis with giant cells and cholesterol clefts. In two subjects bronchoalveolar lavage was performed and the lavage fluid contained more than $70 \%$ lymphocytes in each case. Bronchial provocation tests with the humidifier antigen in these two workers reproduced their symptoms. Unlike previously reported cases, where exposure was to humidifiers working at generally higher temperatures, challenge with thermophilic actinomyctes in our two patients produced no reaction. Tests for precipitins to the humidifier antigen gave strongly positive reactions in the three workers but no single organism isolated from the humidifier produced a significantly positive reaction.
\end{abstract}

Humidifier fever is probably the best recognised illness associated with exposure to a contaminated humidifier. ${ }^{1}$ Classically this consists of a work related influenza like condition that starts when a person returns to work after a period away. ${ }^{2}$ There is usually a delay of some four to eight hours before symptoms occur. Tolerance develops with repeated exposure and symptoms wane some 48 hours after the return to work. ${ }^{3}$ The term humidifier lung is currently reserved for the physiological changes occurring in the lung after an acute exposure to contaminated humidifier water. The functional features are a restrictive ventilatory defect, a reduction in gas transfer, and occasionally evidence of airways obstruction; measurements obtained before a shift are usually normal. ${ }^{2}$ Humidifier lung seems to differ from most forms of extrinsic allergic alveolitis by not giving rise to radiographic abnormalities or to permanent changes in lung function (although clearly such changes are not necessary for a diagnosis of extrinsic allergic alveolitis). ${ }^{4}$ This difference may arise because the specific physical properties of the soluble antigen of the humidifier droplet differ from those of the particulate antigens of vegetable dusts. ${ }^{5}$ The prevalence of humidifier lung in those who complain of humidifier fever is unknown. The cause or causes of humidifier lung or indeed humidifier fever itself

Address for reprint requests: Dr A S Robertson, Department of Thoracic Medicine, East Birmingham Hospital, Birmingham B9 5ST.

Accepted 26 August 1986 remain unclear, although endotoxins are strongly implicated in both. ${ }^{6}$

In 1970 Banaszak and colleagues were the first to describe extrinsic allergic alveolitis due to a humidifier occurring among office workers. ${ }^{7}$ All four workers described had abnormal chest radiographs. The cause was thought to be a thermophilic organism similar to Micropolyspora faeni, which was isolated from the humidifier. Most of the subsequent reports of humidifier related extrinsic allergic alveolitis with radiographic abnormalities have been described with exposure to home cool mist and furnace humidifiers. $^{8-16}$ These contain water that is warm and may become grossly contaminated with thermophilic microorganisms. There have been only five further published reports of contaminated industrial and office cold water humidifiers giving rise to an extrinsic allergic alveolitis with radiographic abnormalities. ${ }^{1417-20}$ In two of the cases from the United States thermophilic organisms have been strongly implicated, with positive reactions to inhalation challenges and corresponding precipitins found in the patients.

Most of the organisms found in these contaminated humidifiers, such as $M$ faeni, Thermoactinomyces vulgaris, and Aspergillus fumigatus, are well recognised as causing extrinsic allergic alveolitis in different circumstances, such as in farmer's lung.

We report three cases of extrinsic allergic alveolitis not due to thermophilic organisms, occurring in workers in a printing factory who were exposed to a 
Table 1 Lung function at presentation $(A)$ and after treatment $(B)$, expressed as percentages of predicted values

\begin{tabular}{|c|c|c|c|c|c|c|}
\hline & \multicolumn{2}{|c|}{ Subject I } & \multicolumn{2}{|c|}{ Subject 2} & \multicolumn{2}{|c|}{ Subject 3} \\
\hline & $A$ & $B(2 y)$ & $A$ & $B(2 y)$ & $A$ & $B(10 y)$ \\
\hline $\begin{array}{l}\text { FEV } \\
\text { Forced vital capacity } \\
\text { Total lung capacity } \\
\text { Transfer coefficient } \\
\text { Transfer factor }\end{array}$ & $\begin{array}{r}55 \\
85 \\
100 \\
55 \\
49\end{array}$ & $\begin{array}{r}65 \\
90 \\
100 \\
60 \\
55\end{array}$ & $\begin{array}{l}70 \\
82 \\
92 \\
54 \\
45\end{array}$ & $\begin{array}{l}78 \\
99 \\
96 \\
63 \\
61\end{array}$ & $\begin{array}{l}80 \\
85 \\
70 \\
52 \\
45\end{array}$ & $\begin{array}{r}100 \\
85 \\
80 \\
95 \\
75\end{array}$ \\
\hline
\end{tabular}

Table 2 Bronchoalveolar lavage fluid: differential cell content

\begin{tabular}{lcc}
\hline & Subject I & Subject 2 \\
\hline Lavage volume $(\mathrm{ml})$ & 180 & 180 \\
Volume returned $(\mathrm{ml})$ & 74 & 45 \\
Cell yield $\left(\times 10^{6} / \mathrm{ml}\right)$ & $1 \cdot 1$ & $0 \cdot 6$ \\
Lymphocytes $(\%)$ & 75 & $74 \cdot 5$ \\
Macrophages $(\%)$ & 17 & 15 \\
Neutrophils $(\%)$ & 8 & 10 \\
Eosinophils $(\%)$ & 0 & 0 \\
Epithelial cells $(\%)$ & 0 & $0 \cdot 5$ \\
\hline
\end{tabular}

contaminated humidifier with the water at $15^{\circ} \mathrm{C}$.

\section{Case histories}

Subject 1 was a 53 year old man who worked as a progress chaser for 20 years in the printing factory.
Over a period of five months he had noticed increasing breathlessness on exercise and a persistent cough. He had lost $4 \mathrm{~kg}$ in weight. Before this he had had nocturnal wheeze and breathlessness and occupationally related asthma had been demonstrated. ${ }^{21} \mathrm{He}$ had never kept birds. On examination he did not have finger clubbing but he did have splinter haemorrhages in his nail beds. Auscultation of his chest revealed late inspiratory crackles in both mid and lower zones.

Subject 2 was a 41 year old man who also worked for the past 20 years in the same printing factory as a cross cutter. He gave a past history of typical humidifier fever over the previous five years. For four months, however, he had noticed increasing cough and breathlessness with minimal exercise. He had lost $3 \mathrm{~kg}$ in weight. Again there was no history of exposure to birds. Examination showed that he had no finger

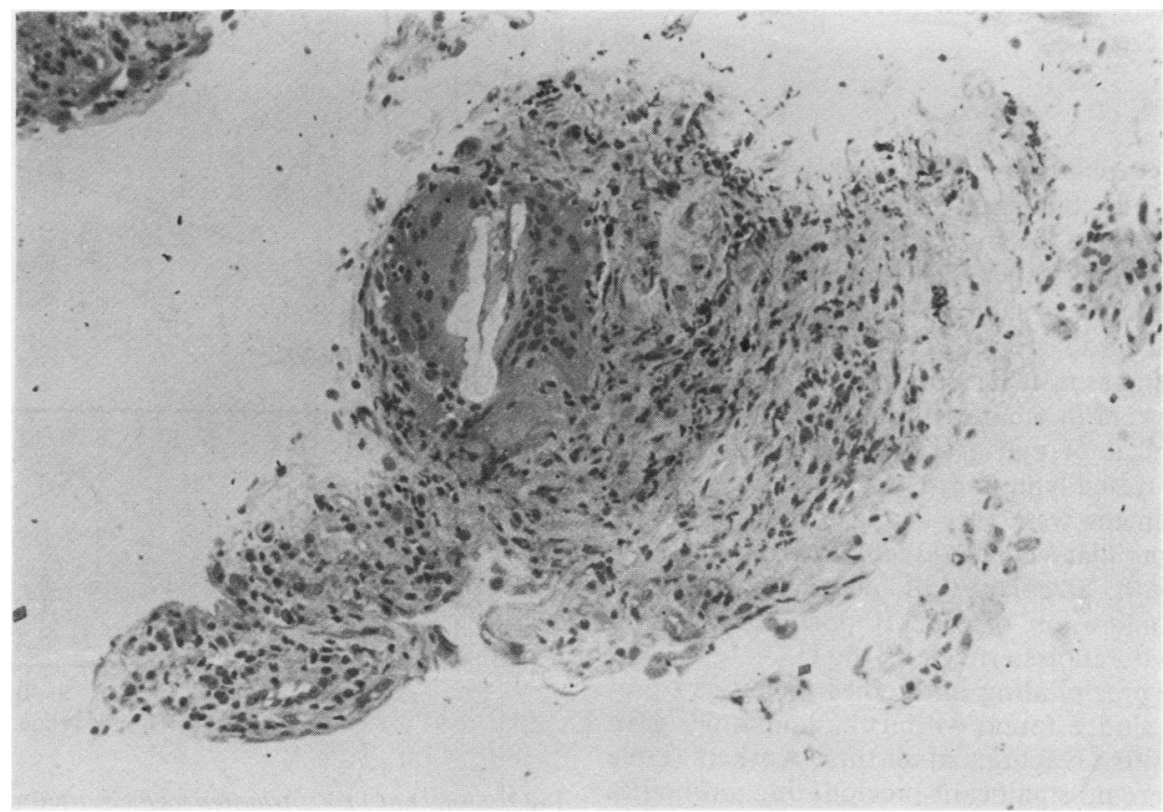

Fig 1 Transbronchial lung biopsy from subject 1 showing a giant cell with a cholesterol cleft. Other features of alveolar wall oedema, proliferation of type II pneumocytes and interstitial fibrosis were also present. 
Table 3 Results of precipitating antibody tests

\begin{tabular}{|c|c|c|c|}
\hline & Subject I & Subject 2 & Subject 3 \\
\hline Aspergillus fumigatus & - & - & - \\
\hline Micropolyspora faeni & - & - & - \\
\hline Thermoactinomyces vulgaris & - & - & - \\
\hline Budgerigar droppings & + & + & + \\
\hline Budgerigar serum & - & - & - \\
\hline Pigeon droppings & + & + & + \\
\hline Pigeon serum & - & - & - \\
\hline Humidifier antigen & $+t+$ & +++ & +++ \\
\hline
\end{tabular}

clubbing, but he had both mid and lower zone crackles and wheezes.

Subject 3 was a 57 year old woman who started working in the same building as subjects 1 and 2 some 23 years ago. Her initial job was as a fanner and gummer but most of her time had been spent as an inspector. Two years after starting work there she developed typical symptoms of humidifier fever. At the same time she noticed episodes of chest tightness and wheezing, which were worse at night and better during a period away from work. Ten years later she developed weight loss, persistent cough, and increasing breathlessness on exertion. A mass miniature chest radiograph was reported as normal but a biochemical screening survey at the factory showed a high serum globulin concentration, which resulted in her referral. There had been a budgerigar at home when she was seven. On examination she did not have finger clubbing, but she did have bilateral crackles with no wheezes.

\section{Investigations}

Chest radiographs in all three workers were abnormal. Scattered, bilateral, nodular shadows were present, mainly in the mid and lower zones. Initial lung function tests (table 1) showed considerable airways obstruction in subject 1 . Lung volumes were preserved except in subject 3, but all the workers had a reduction in gas transfer. Bronchoalveolar lavage in the two workers in whom it was performed showed changes typical of extrinsic allergic alveolitis with appreciably raised lymphocyte counts (table 2 ). Lung biopsy specimens were very similar in all three subjects, showing classical features of extrinsic allergic alveolitis with alveolar wall oedema, interstitial fibrosis, proliferation of type II pneumocytes, and giant cells with cholesterol clefts (fig 1).

Tests for precipitating antibodies to antigen prepared from sludge found within the humidifier gave strongly positive reactions in all three workers (table 3 ). There were no significant precipitating antibodies to antigens from any of the 70 separate microorganisms so far cultured from the humidifier. Precipitins to $M$ faeni, $A$ fumigatus, and $T$ vulgaris were also absent. All three had precipitins to budgerigar and pigeon droppings but not to the serum from these birds. The only one person (subject 3 ) to give a history of contact with birds was exposed only during childhood.

\section{BRONCHIAL PROVOCATION TESTS}

Sludge was collected from the baffle plates contained within the contaminated humidifier. The material obtained was treated for five days with Coca's solution, dialysed, and then freeze dried. When required this was reconstituted with $0.9 \% \mathrm{NaCl}$ to give a concentration of $1 \mathrm{mg} / \mathrm{ml}$. Control provocation tests were
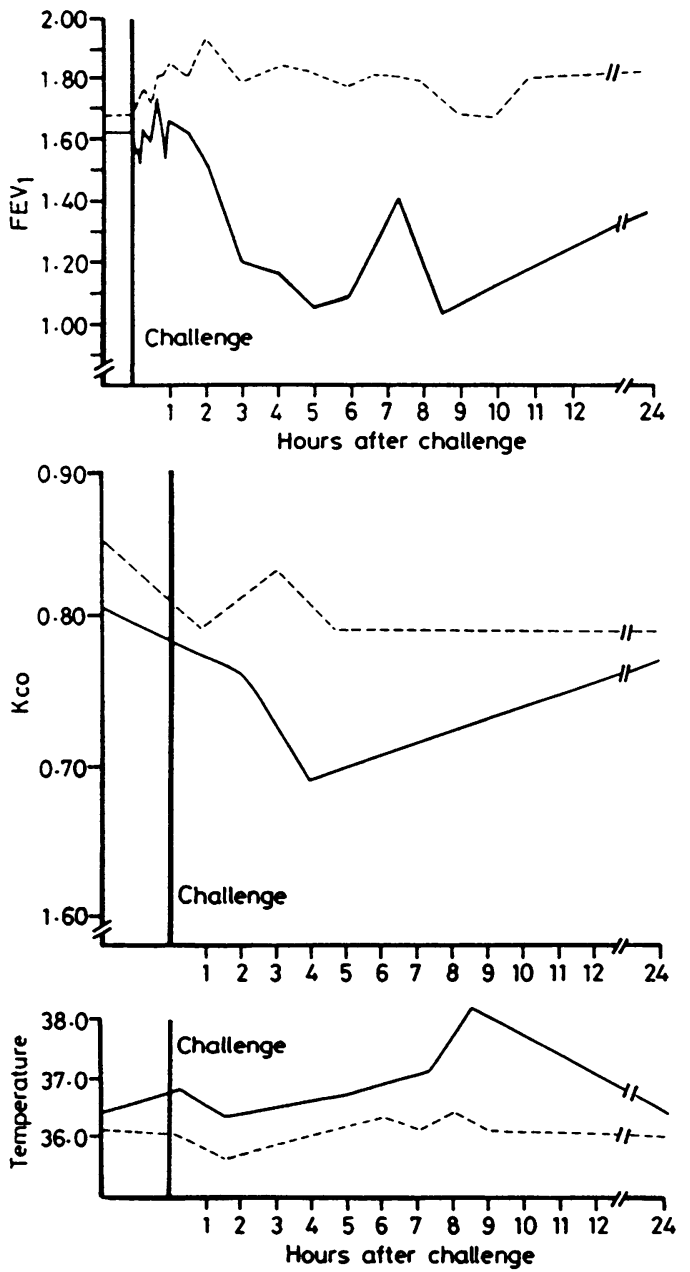

Fig 2 Effect of $F E V_{1}$, transfer coefficient (KCO), and temperature in subject 1 after bronchial challenge with $2 \mathrm{mg}$ humidifier antigen (continuous line) and a control challenge with Micropolyspora faeni (interrupted line). 
Table 4 Lung function response to bronchial challenge with humidifier antigen

\begin{tabular}{|c|c|c|c|c|c|c|c|}
\hline & $F E V_{1}(l)$ & $F V C(l)$ & $\begin{array}{l}F E V_{1} / F V C \\
(\%)\end{array}$ & $\begin{array}{l}T L C O \\
\left(\operatorname{mmol}_{\left.k P a^{-1} l^{-1}\right)}\right.\end{array}$ & $\begin{array}{l}\mathrm{KCO} \\
\left(\mathrm{mmol}_{\mathrm{min}}^{-1}\right. \\
\left.k \mathrm{~Pa}^{-1} l^{-1}\right)\end{array}$ & $V A(l)$ & $\begin{array}{l}\text { Temperature } \\
\left({ }^{\circ} \mathrm{C}\right)\end{array}$ \\
\hline \multicolumn{8}{|l|}{ Subject 1} \\
\hline Baseline & 1.62 & $3 \cdot 23$ & 50 & 5.06 & 0.82 & $6 \cdot 21$ & $36 \cdot 4$ \\
\hline Maximum fall & 1.03 & $2 \cdot 20$ & 47 & $4 \cdot 11$ & 0.69 & $5 \cdot 74$ & $38 \cdot 2$ \\
\hline$\%$ change & 36 & 32 & & 19 & 16 & & 5 \\
\hline \multicolumn{8}{|l|}{ Subject 2} \\
\hline Baseline & $2 \cdot 40$ & 3.85 & 62 & $5 \cdot 78$ & 0.99 & $5 \cdot 89$ & $36 \cdot 8$ \\
\hline Maximum fall & 1.91 & $3 \cdot 34$ & 57 & $4 \cdot 30$ & 0.82 & $5 \cdot 30$ & $38 \cdot 4$ \\
\hline$\%$ change & 20 & 13 & & 26 & 17 & 10 & 4 \\
\hline \multicolumn{8}{|l|}{ Control 1} \\
\hline Baseline & $4 \cdot 11$ & $5 \cdot 01$ & 82 & $12 \cdot 55$ & 1.85 & 6.86 & $36 \cdot 2$ \\
\hline Maximum fall & $4 \cdot 02$ & 4.98 & 81 & $11 \cdot 77$ & $1 \cdot 70$ & $6 \cdot 60$ & $36 \cdot \overline{8}$ \\
\hline$\%$ change & 2 & 1 & & 6 & 8 & 4 & 1 \\
\hline \multicolumn{8}{|l|}{ Control 2} \\
\hline Baseline & $4 \cdot 91$ & $5 \cdot 90$ & 83 & $14 \cdot 44$ & 1.85 & $7 \cdot 83$ & $36 \cdot 3$ \\
\hline Maximum fall & $4 \cdot 72$ & $5 \cdot 75$ & 82 & $13 \cdot 38$ & $1 \cdot 72$ & $7 \cdot 74$ & $36 \cdot 3$ \\
\hline$\%$ change & 4 & 3 & & 7 & 7 & 1 & 0 \\
\hline
\end{tabular}

FVC - forced vital capacity; TLCo-carbon monoxide transfer factor; Kco-transfer coefficient; VA-alveolar volume.

Conversion: SI to traditional units-TLCO and KCO: Multiply SI units by 2.99.

performed with $M$ faeni prepared in a similar manner, again at a concentration of $1 \mathrm{mg} / \mathrm{ml}$. Solutions were nebulised in a Bard nebuliser driven by air for five minutes, giving a total exposure of $2 \mathrm{mg}$. Exposure to this dose, or less, of $M$ faeni has been shown to produce a positive response in sensitive individuals with farmers lung. ${ }^{22}$

Symptoms, clinical signs, temperature, spirometric values, and gas transfer were monitored both before and after the challenge periods.

\section{Results}

RESPONSE TO BRONCHIAL PROVOCATION TESTS Two of the workers ( 1 and 2 ) had bronchial provocation tests performed with antigen prepared from the humidifier sludge.

Two hours after provocation testing both workers looked unwell. Thereafter they developed striking symptoms of headache, generalised aches and pains, lethargy, chills, and fever.

Subject 1 (fig 2) showed an appreciable fall in $\mathrm{FEV}_{1}$, occurring maximally from four to nine hours after the challenge and persisting for at least 24 hours. The gas transfer (TLCO) fell by 19\% and transfer coefficient (KCO) by $16 \%$ (table 4 ). These both returned towards baseline at 24 hours. A similar pattern of response was seen in subject 2 , with a fall in FEV $_{1}(20 \%)$ and gas transfer $(26 \%)$ and a rise in temperature to $38.4^{\circ} \mathrm{C}$ (table 4). Both workers developed bilateral basal crackles after the provocation tests. Crackles had been present in both workers on initial examination but had cleared in the period between removal from work and provocation testing.

Two non-exposed asthmatic subjects had identical provocation tests with the same concentration of humidifier antigen and with identical postchallenge monitoring. There were no appreciable subjective or objective changes in either subject (table 4).

\section{FOLLOW UP}

Subjects 1 and 2 immediately stopped work. Work related symptoms of headache, lethargy and generalised aches and pains did not return after exposure ceased. The splinter haemorrhages in subject 1 disappeared within a few days of leaving work. The bilateral crackles also cleared in both men. Radiographic abnormalities persisted. Subsequently both patients were treated with oral prednisolone, initially in a dose of $40 \mathrm{mg}$ daily. There was an increase in weight and cough gradually resolved in both. Subjective exercise tolerance also improved to a fixed level-both now have breathlessness when walking on level ground with someone of their own age but not when walking at their own pace. There was considerable clearing of the radiographic shadowing in both men, subject 2 returning to normal. There was also an initial improvement in lung function in subjects 1 and 2 , TLCo increasing by $6 \%$ and $16 \%$ and $\mathrm{Kco}$ by $5 \%$ and $9 \%$ respectively; but values remain considerably reduced and have been static for some time (table 1 ).

Subject 3 was also treated with steroids but continued to be exposed at work. At first she felt much improved, her exercise tolerance increased, and there was an improvement in lung function. Two years later her lung function and radiographic appearances deteriorated; steroids were increased and azothioprine was added. Thereafter there was a further improvement, KCo increasing to $95 \%$ and TLCO to $75 \%$ of predicted values (table 1 ). 


\section{Discussion}

The close control of relative humidity at around $55 \%$ is particularly important in the printing industry, where changes in moisture content affect the size of the paper. The humidifiers used in this plant were cold water spray humidifiers using chilled water at $15^{\circ} \mathrm{C}$, which recirculated from the sump. A proportion of the air from the works is recirculated through the system and, as in many other printing works, the humidifier is particularly prone to bacterial contamination.

All three patients had had recognisable work related symptoms of humidifier fever or occupational asthma or both for some years before a noticeable change occurred. Their symptoms became persistent, with weight loss, deteriorating breathlessness, and cough. Radiographic and histological changes were very similar in all three cases. A predominantly lymphocytic cell count content in the bronchoalveolar lavage fluid is classically found in either sarcoidosis or extrinsic allergic alveolitis. Lymphocyte counts greater than $70 \%$ are very rarely found in sarcoidosis and are more commonly found in extrinsic allergic alveolitis. ${ }^{2324}$ Kveim biopsy samples were negative for sarcoidosis in all three workers.

In most cases of extrinsic allergic alveolitis due to contaminated humidifiers reported from the United States thermophilic organisms have been isolated from the humidifiers. Precipitating antibodies to these organisms were usually found and when performed, bronchial challenges to these organisms produced positive responses. In the three patients reported here, although precipitins to the humidifier antigen were strongly positive, no single organism so far isolated from the humidifier or any other thermophilic organism tested was significantly positive. A previously reported study of 258 volunteers from this factory showed precipitins to the humidifier antigen present in all those workers with humidifier fever. Although those investigated had not been randomly sampled, precipitins were also present in $63 \%$ of the symptom free workers. ${ }^{25}$

The finding of precipitating antibodies to avian droppings but not to avian serum, with no appreciable past exposure to birds in two of the subjects, suggests either that a similar organism occurred in both the humidifier sludge and the bird droppings or that cross reacting antibodies are present. In the same way, precipitating antibodies to budgerigar droppings but not to budgerigar serum was found in patients with Japanese summer alveolitis. ${ }^{26} \mathrm{~A}$ fungal species, Trichosporon cutaneum, was found to be common to the budgerigar droppings and to dust sampled from the houses. A subsequent bronchial provocation test using the fungal antigen gave positive responses.
The changes following exposure to antigen in patients (mainly bird fanciers) with extrinsic allergic alveolitis have been carefully studied by Hendrick and colleagues. ${ }^{4}$ They found that a fall in TLCo was specific but not sensitive. Clinical features of an unwell appearance, symptoms of malaise, widespread aches and pains, headache, and fever were the commonly found changes in patients in whom the disease was classically that of extrinsic allergic alveolitis. Our patients showed similar features after exposure. The specificity of the response in our patients was shown by the complete lack of subjective or objective change after the same provocation testing in two nonexposed asthmatic subjects. Although patients with humidifier fever may show similar changes on provocation testing, such as a reduced gas transfer, these changes do not persist after they have been removed from exposure. ${ }^{2} 27$

The cause or causes of humidifier related lung disease remains unclear. The endotoxic components of Gram negative bacteria have been strongly implicated in the production of humidifier fever. High levels of endotoxin have been found where water has become grossly contaminated with Gram negative bacteria. This has been found to occur in humidifiers with organisms such as Pseudomonas ${ }^{6}$ and also in lake water, where inhalation challenges with the contaminated water reproduced the symptoms. ${ }^{28}$ Inhalation challenges with humidifier water have also been performed where the reaction was thought unlikely to be due to endotoxin. Edwards and Cockcroft ${ }^{27}$ reproduced humidifier fever in some sensitive individuals. They considered, however, that the reaction was unlikely to be caused by endotoxin because no reaction occurred in rabbits after they had been inoculated intravenously with a concentrate of the humidifier water. Challenges solely with endotoxin, until recently, had not mimicked the typical features of humidifier fever. ${ }^{29}$ Recently Rylander ${ }^{30}$ performed inhalation challenges using different endotoxin preparations of Enterobacter agglomerans on symptomless, previously unexposed individuals. He found falls in FEV 1 and TLCO and a pyrexial response to inhalation challenge with the purified endotoxin, but there was no fall in TLCO when he used endotoxin associated with the cell wall. Others performing similar endotoxin challenges in unexposed subjects have obtained different results, with a fall in TLCo but no symptomatic effects and little change in spirometric values. $^{31}$ Further evidence of a possible bacterial cause of humidifier alveolitis has come from the isolation of Cytophagia allerginiae from the humidifier water in a textile works were an outbreak of alveolitis occurred. ${ }^{32}$ Out of the 700 organisms found, this endotoxin containing, Gram negative bacterium appeared to be the organism causing the alveolitis. 
The specificity was determined by serological testing only and no inhalational challenges have yet been reported.

The factors determining the host's reaction to a contaminated humidifier remain unknown. The bacterial source of the antigen, its mode of delivery whether it is soluble or particulate, the dose, and the host's susceptibility must all be considered.

Contaminated humidifiers should be thought of as a possible occult cause of extrinsic allergic alveolitis in cases where no obvious reason has been found.

Thanks are due to Dr CW Edwards for preparation and interpretation of the histological specimens. ASR is funded by a Sheldon fellowship administered by the West Midlands Regional Health Authority.

\section{References}

1 Pestalozzi VC. Febrile Gruppenerkrankungen in einer Modellschreinerei durch Inhalation von mit Schimmelpilzen kontaminiertem Befeuchterwasser. ("Befeuchterfieber"). Schweiz Med Wochenschr 1959;27:710-3.

2 Friend JAR, Gaddie J, Palmer KNV, Pickering CAC, Pepys J. Extrinsic allergic alveolitis and contaminated cooling-water in a factory machine. Lancet 1977;i:297-300.

3 Pickering CAC, Moore WKS, Lacey J, Holford-Strevens VC, Pepys J. Investigations of a respiratory disease associated with an air-conditioning system. Clin Allergy 1976;6:109-18.

4 Hendrick DJ, Marshall R, Faux JA, Krall JM. Positive "alveolar" responses to antigen inhalation provocation tests: their validity and recognition. Thorax 1980;35:415-27.

5 Salvaggio J, Phanuphak P, Stanford R, Bric D, Claman $H$. Experimental production of granulomatous pneumonitis. J Allergy Clin Immunol 1975;56:364-80.

6 Rylander R, Haglind P. Airborne endotoxins and humidifier disease. Clin Allergy 1984;14:109-12.

7 Banaszak EF, Theide W.H, Fink JN. Hypersensitivity pneumonitis due to contamination of an air conditioner. N Engl J Med 1970;283:271-6.

8 Fink JN, Banaszak EF, Theide WH, Baboriak JJ. Interstitial pneumonitis due to hypersensitivity to an organism contaminating a heating system. Ann Intern Med 1971;74:80-3.

9 Burke GW, Carrington CB, Trauss R, Fink JN, Gaensler EA. Allergic alveolitis caused by home humidifiers. JAMA 1977;238:2705-8.

10 Van Assendelft A, Forsen K-O, Keskinen H, Alanko K. Humidifier-associated extrinsic allergic alveolitis. Scand J Work Environ Health 1979;5:35-41.

11 Hodges GR, Fink JN, Schlueter DP. Hypersensitivity pneumonitis caused by a contaminated cool-mist vaporizer. Ann Intern Med 1974;80:501-4.

12 Sweet LC, Anderson JA, Callies QC, Coates EO. Hypersensitivity pneumonitis related to a home furnace humidifier. J Allergy Clin Immunol 1971;48:171-8.

13 Tourville DR, Weiss WI, Wertlake PT, Leudemann GM.
Hypersensitivity pneumonitis due to contamination of home humidifier. $J$ Allergy Clin Immunol 1972;49:245-51.

14 Fink JN, Banaszak EF, Baroriak JJ, et al. Interstitial lung disease due to contamination of forced air systems. Ann Intern Med 1976;84:406-13.

15 Miller MM, Patterson R, Fink JN, Roberts M. Chronic hypersensitivity lung disease with recurrent episodes of hypersensitivity pneumonitis due to a contaminated central humidifier. Clin Allergy 1976;6:451-62.

16 Marinkovich VA. Hypersensitivity alveolitis. JAMA 1975;231:944-7.

17 Arnow PM, Fink JN, Schlueter DP, et al. Early detection of hypersensitivity pneumonitis in office workers. Am J Med 1978;64:236-42.

18 Robertson AS, Burge PS, Wieland A. Extrinsic allergic alveolitis to antigen from a humidifier at $15^{\circ} \mathrm{C}$ [abstract]. Thorax 1985;40:229.

19 Anderson K, McSharry CP, Boyd G. Radiographic changes in humidifier fever. Thorax 1985;40:312-3.

20 Keller H, Spengler H, Latscha V. Befeuchterfieber. Schweiz Med Wochenschr 1972;102:865-72.

21 Burge PS, Finnegan M, Horsfield N, et al. Occupational asthma in a factory with a contaminated humidifier. Thorax 1985;40:248-54.

22 Edwards JH, Davies BH. Inhalation challenge and skin testing in farmer's lung. $J$ Allergy Clin Immunol 1981;68:58-64.

23 Weinberger SE, Kelman JA, Elson NA, et al. Bronchoalveolar lavage in interstitial lung disease. Ann Intern Med 1978;89:459-66.

24 Reynolds HY, Fulmer JD, Kazierowski JA, Roberts WC, Frank MM, Crystal RG. Analysis of cellular and protein content of broncho-alveolar lavage fluid from patients with idiopathic pulmonary fibrosis and chronic hypersensitivity pneumonitis. $J$ Clin Invest 1977;59:165-75.

25 Finnegan MJ, Pickering CA, Davies PS, Austwick PK. Factors affecting the development of precipitating antibodies in workers exposed to contaminated humidifiers. Clin Allergy 1985;15:281-92.

26 Shimazu K, Ando M, Sakata T, Yoshida K, Araki S. Hypersensitivity pneumonitis induced by Trichosporon cutaneum. Am Rev Respir Dis 1984;130:407-11.

27 Edwards JH, Cockcroft A. Inhalation challenge in humidifier fever. Clin Allergy 1981;11:227-35.

28 Muittari A, Rylander R, Salkinoja-salonen M. Endotoxin and bath-water fever. Lancet 1980;ii:89.

29 Cavagna G, Foa V, Vigliani EC. Effects in man and rabbits of inhalation of cotton dust or extracts and purified endotoxins. Br.J Ind Med 1969;26:314-21.

30 Rylander $\mathbf{R}$. The role of endotoxins in humidifier disease. Humidifier's and air-conditioners' diseases. Colloque INSERM 1986;135:179-92.

31 Jamison JP, Lowry RC. Bronchial challenge of normal subjects with the endotoxin of Enterobacter agglomerans: isolated from cotton dust. $\mathrm{Br} J$ Ind Med 1986;43:327-31.

32 Liebert CA, Hood MA, Deck FH, Bishop K, Flaherty DK. Isolation and characterization of a new Cytophaga species implicated in a work-related disease. Appl Environ Microbiol 1984;48:936-43. 